\title{
Effect of Capital Adequacy Ratio (CAR) on Profitability of Deposit Money Banks (DMB's): A Study of DMB's with International Operating License in Nigeria
}

\author{
Ajayi, Samuel Olatayo*1 $\quad$ Ajayi, Henry Folusho ${ }^{1,2} \quad$ Enimola, Dare Joseph ${ }^{1,3} \quad$ Orugun, Fausat Ibidunni ${ }^{1}$ \\ 1.Department of Banking and Finance, Faculty of Management Sciences, \\ Kogi State University, Anyigba, Nigeria \\ 2.Guaranty Trust Bank, Yola, Adamawa State, Nigeria \\ 3.Department of Business Administrations, Faculty of Management Sciences, \\ Kogi State University, Anyigba, Nigeria
}

\begin{abstract}
The study examined the Effect of Capital Adequacy Ratio (CAR) on Profitability of Deposit Money Banks (DMB's) as obtained from their annual report for 2017 using their Return on Assets (RoA) as Profitability parameter. OLS method was used via SPSS 20.0 to run the data used in the research with findings that; there exist a strong positive relationship between CAR and ROA of Deposit Money Banks (DMB's) in Nigeria and recommends that the banks' regulators should not only focus on Capital Adequacy but also on strategic monitoring and evaluation to maintain banks' financial strength and stability in Nigeria.
\end{abstract}

Keywords: Capital Adequacy Ratio (CAR), Profitability, Deposit Money Banks (DMB’s)

DOI: $10.7176 /$ RJFA/10-10-10

Publication date:May $31^{\text {st }} 2019$

\subsection{Introduction}

1.1 Capital, Capital Adequacy Ratio (CAR), Capitalization and Profitability

In Banking context, Aruwa \& Naburgi (2014), impressively project Capital, Capital Adequacy Ratio (CAR) and Capitalization thus:

"Capital is the cornerstone of a bank's financial strength. It supports bank operations by providing a buffer to absorb unanticipated losses from its activities and in the event of problems, enabling the bank to continue to operate in a sound and viable manner while the problems are addressed or resolved. The maintenance of adequate capital reserves by a bank can engender confidence in the financial soundness and stability of the bank by providing continued assurance that it will honour its obligations to depositors and creditors. A measure of the capital strength of a bank is the capital adequacy ratio, which is the amount of a bank's regulatory capital expressed as a percentage of its risk-weighted assets. Prudential guidelines on 'Capital Adequacy' sets out the three main elements that determine a bank's capital adequacy. These are: credit risk associated with exposures; market risk arising from banking activities and the form and quality of capital held to support these exposures. Traditional approaches to bank regulation emphasize the view that the existence of capital adequacy regulation plays a crucial role in the long-term financing and solvency position of banks, especially in helping the banks to avoid bankruptcies and their negative externalities on the financial system. In general, capital or net worth serves as a buffer against losses and hence failure. In addition to this, the performance of the banks would also be enhanced although this has not been empirically investigated. Capitalization is an important component of reforms in the Nigeria banking industry, owing to the fact that a bank with a strong capital base has the ability to absolve losses arising from non performing liabilities..." (para 1\&2).

By profitability we do not mean profit before or after tax of banks but their "profit-ability". This simply explains the plausibility in these banks to generate profit. This plausibility is assessed using profitability ratios (Ajayi, Ajayi, Enimola \& Orugun, 2019). Profitability Ratio explains efficiency or otherwise in the use of assets (Richards and Stewart, 1996).

\subsection{Problem of the Study}

In recent times, from 2004 to 2019, the Nigeria banking industry experienced set of reforms, that are geared towards enhancing operational efficiency of banks in Nigeria such that they can compete globally. The Soludo reform thrusts on improving Capital Adequacy while the Sanusi reform thrusts on sustenance of Capital Adequacy. Threat to Capital Adequacy include (but not limited to), disclosureness, corporate governance structure, government policy, inflation rate and GDP growth rate.

This study attempts to assess the effects of Capital Adequacy on Corporate Profitability of Deposit Money Banks (DMB's) in Nigeria. 


\subsection{Research Question}

From the statement of problem above, the Research Question is generated thus: Is there strong and positive relationship between Capital Adequacy and Profitability of Deposit Money Banks in Nigeria?

\subsection{Objectives of The Study}

With the general objective of examining the effect of Capital Adequacy on Profitability of Deposit Money Banks in Nigeria; the specific objective is to ascertain the nature and strength of relationship between Capital Adequacy and Profitability of Nigeria's DMB's.

\subsection{Research Hypothesis}

$\mathrm{H}_{0}$ : There is no strong and positive relationship between Capital Adequacy and Profitability of Deposit Money Banks in Nigeria (DMB's).

\subsection{Significance of the Study}

This study would aid strong assertiveness in discussing the influence of Capital Adequacy on Nigeria' s Deposit Money Banks (DMB's) Profitability.

\subsection{Scope of The Study}

Return on Assets (RoA) is considered as the parameter for measuring profitability while Capital Adequacy Ratio (CAR) is the parameter used to measure Capital Adequacy-note also that amongst Deposit Money Banks in Nigeria, just a few with international operating license is considered. They include: Zenith Bank, Access Bank, UBA, First Bank, Union Bank, Fidelity Bank, First City Monument Bank (FCMB) and Guaranty Trust Bank. From the foray of DMB's in Nigeria, these selected eight (8) have better Availability, Visibility and Accessibility than others. On strata basis, findings based on operation of Banks in this tier will be robust enough to form a decision for DMB's operations in Nigeria.

\subsection{Literature Review \\ 2.1 Conceptual Framework Capital Adequacy Ratio (CAR)}

The Capital Adequacy Ratio , also known as capital to Risk-Weighted Assets Ratio, measures a bank's financial strength by using its capital and assets. It is used to protect depositors and promote the stability and efficiency of financial systems around the world. Generally, a bank with a high Capital Adequacy Ratio is considered safe and likely to meet its financial obligations. The Capital Adequacy Ratio is calculated by dividing a bank's capital by its risk-weighted assets. The capital used to calculate the capital adequacy ratio is divided into two tiers. Tier-One Capital, or Core Capital, is comprised of Equity Capital, Ordinary Share Capital, Intangible Assets and Audited Revenue Reserves. Tier-One Capital is used to absorb losses and does not require a bank to cease operations. Tier Two Capital comprises Unaudited Retained Earnings, Unaudited Reserves and General Loss Reserves. This capital absorbs losses in the event of a company winding up or liquidating. The two capital tiers are added together and divided by risk-weighted assets to calculate a bank's capital adequacy ratio. Risk-weighted assets are calculated by looking at a bank's loans, evaluating the risk and then assigned a weight. Currently, the minimum ratio of capital to risk-weighted assets is eight percent under Basel II and 10.5 percent under Basel III. High capital adequacy ratios are above the minimum requirements under Basel II and Basel III. Minimum capital adequacy ratios are critical in ensuring that banks have enough cushion to absorb a reasonable amount of losses before they become insolvent and consequently lose depositors' funds (Brian, 2018).

Profitability

Bank profitability is an important ingredient of financial development, its relevance spans through banking firm performance to macroeconomic stability. At the firm level, a higher return to a large extent reduces bank fragility. At the macro level, increased profitability makes for a sustainable banking sector that can finance economic growth and development. However, due to the intermediation role of the banking system, higher returns may imply higher interest rates on loans. This informs a reason why monetary authorities are always poised to regulating the banking system. Increased regulations and counter deregulations have encouraged competition in the banking sector, and hence exposed banks to increased fragility (Ozuagwu, 2014). There are three widely known measures of bank profitability. The three indicators are Net Interest margin (NIM), Return on Assets (ROA) and Return on Equity (ROE). These are divergent views among scholars on the superiority of one indicator over the other as a good measure of profitability in banks. Similarly, anyone or a combination of the indicators can be used to measure profitability in banks depending on the objective of the user or analyst. If the objective is to measure how profitable and efficient the management of a bank is in using the bank's total assets to generate income, Return on Assets (ROA) becomes the most vital indicator to employ. The study adopted Return on Assets (ROA) as a measure of profitability in banks because ROA measures how profitable and efficient the management of a bank is in using 
the bank's total assets in generating income (Ndifon \& Ubana 2014).

\subsection{Theoretical Framework}

This study will be based on three theories of Capital Adequacy. They are: Buffer Theory, Deposit Insurance Theory, and Expense Theory. However, the Buffer Theory is considered most suitable for this study as it in consonance with Nigeria's Central Bank's approach in ensuring Capital Adequacy for its banks operational efficiency.

According to Buffer Theory of Capital Adequacy, banks may prefer to hold a "buffer" of excess capital to reduce the probability of falling under the legal capital requirements, especially if their capital adequacy ratio is very volatile (Aruwa \& Naburgi, 2014). The Deposit Insurance Theory asserts that banks are viewed as portfolio of risky claims. As insured banks increase their risk of failure without limit, there is an expected value transfer of wealth from government deposit Insurance Corporation to bank owners. Regulators are concerned about bank's soundness, particular with respect to solvency or the probability of bank failure (Flannery, 1989; Cham, Greenbaum \& Anjan, 1992; Aruwa \& Naburgi, 2014). Expense Theory otherwise called the Theory of Managerial Discretion posits that, managers have the option in pursuing policies, which maximize their own utility rather than profit maximization for shareholders (Nyong, 2001).

In line with the Buffer Theory, capital requirements constitute is a fundamental banking supervisory instrument in Nigeria. The Central Bank of Nigeria (CBN) intervenes little in banks' activities but does directly conduct on-site examination and at times delegating this task to external auditors. By contrast, a breach of the capital requirements is considered a major infringement of banking legislation and is not tolerated by the Central Bank of Nigeria (CBN). Banks remaining undercapitalized for prolonged periods are closed. The withdrawal of some banking licenses at the expiration of the recent recapitalization of banks in Nigeria in 2005 is a pointer to this fact. Banks will require more capital if deposits are not fully mobilized from the public. Capital is more reliable, dependable and can be used for long term planning. Ability of banks to mobilize enough deposits obviates the capital base from being eroded (Aruwa \& Naburgi 2014). The buffer theory of Calem \& Rob (1996) as cited in Aruwa \& Naburgi 2014) predicts that a bank approaching the regulatory minimum capital ratio may have an incentive to boost capital and reduce risk in order to avoid the regulatory costs triggered by a breach of the capital requirements. Poorly capitalized banks may also be tempted to take more risk in the hope that higher expected returns will help them to increase their capital. This is one of the ways risks relating to lower capital adequacy affects banking operations. In the event of bankruptcy of a bank, the risks are absorbed by the bank, customers and Nigeria Deposit Insurance Corporation (NDIC). At present NDIC pays a maximum of N200, 000 to a customer in the event of bank failure (Aruwa \& Naburgi 2014). Hence, customers are concerned about capital position of banks at all time. Banks are expected to insure and pay $15 / 16$ of customers deposit liabilities multiplied by $1 \%$ to NDIC to enable their customers benefit from the scheme. Aruwa \& Naburgi further affirmed that the above practice of NDIC in Nigeria is applicable to other countries but varies in amount.

\subsection{Empirical Review}

Asikhia \& Sokefun (2013), examined the effect of capital adequacy on profitability of deposit- taking banks in Nigeria. The study seeks to assess the effect of Capital Adequacy of both foreign and domestic banks in Nigeria and their profitability. The paper present primary data collected by questionnaires involving a sample of 518 distributed to staff of banks with a response rate of $76 \%$. Also published financial statement of banks were used from 2006 - 2010. The findings for the primary data analysis revealed a non-significant relationship but the secondary data analysis showed a positive and significant relationship between capital adequacy and profitability of bank. This implies that for deposit- taking banks in Nigeria, capital adequacy plays a key role in the determination of profitability. It was discovered that capitalization and profitability are indicators of bank risk management efficiency and cushion against losses not covered by current earnings.

Abba, Inyang \& Zachariah (2013), examined the relationship between capital adequacy and banking risks. Three independent variables were used. These variables are risk-weighted asset ratio, deposit ratio and inflation rate. Twelve banks were sampled from the population of twenty-two banks in the Nigerian banking industry as at December, 2013. Secondary data were collected from the financial statements of the banks for a period of five years, from 2007 to 2011. Value at risk theory was adopted to estimate capital adequacy ratio of the banks. The hypothesis was tested using the results of the multiple regression analysis carried out. The model is fitted as there is absence of serial correlation and multicollinearity based on the Durbin Watson result of approximately 2, tolerance values of less than 1 and VIF values of less than 10 for the coefficients of the model. Changes in capital adequacy ratio are explained by changes in the independent variables, up to $35 \%$. It was therefore, observed that there is a significant negative relationship between risk and capital adequacy ratio of banks, which means when risk level rises, capital adequacy ratio falls in the Nigerian banking industry. Affirming that Capital adequacy ratio is an important measure of "safety and soundness" for banks and depository institutions because it serves as a buffer or cushion for absorbing losses; the study recommends that Nigerian banks should adopt a risk-based approach in managing capital instead of the present practice of focusing on the paid-up capital and retained 
earnings as there is significant relationship between capital adequacy ratio and banking risks. Since the research has also provided evidence of negative relationship between deposits and capital adequacy ratio, we also recommend that Nigerian banks should adopt pragmatic approaches to guarantee the safety of depositor's money since increase in deposits does not necessarily result to increase in capital adequacy ratio.

Oyedokun,(2013), examined the trends and patterns of change in the capital levels and efficiency of Nigerian Commercial Banks. This was with a view to providing empirical information on the relationship between capital base requirements and profit-generating capacity and efficiency of the banks. The study utilized secondary data covering 16 years on the commercial banks in existence between 1992 and 2007. Data on Key Performance Indicators of the banks such as Total Income, Interest Rates, Total Credits, And Branch Networks were sourced from the "fact books" published by the Nigerian Stock Exchange (NSE) and official publications of the selected banks. Descriptive statistical techniques were used to appraise the trends and patterns of The Key Performance Indicators in relation to changes in capital base of the banks over the studied period. The results showed that capital base requirement was ineffective in reducing distress in the banking industry. Also, the capital base requirement by the Central Bank of Nigeria lagged behind the average capital base of the banks. The study concluded that the Central Bank of Nigeria could use the regulatory power of raising the capital base of banks to stimulate greater profitability and efficiency in the banking sector.

Ndifon \& Ubana (2014), examined the Impact of Capital Adequacy on Deposit Money Banks' Profitability in Nigeria,main objective of this paper is to empirically assess the impact of capital adequacy on Deposit Money Banks' profitability in Nigeria, taking a case study of five selected banks. The empirical analysis covered the period from 1981 to 2011 . The data for the study were obtained from secondary sources including the annual reports and financial statements of the selected banks and Central Bank of Nigeria (CBN) statistical bulletin. The study adopted the Engle and Granger two steps procedure in co-integration. The study revealed that capital adequacy plays an important role in explaining banks Returns on Assets (ROA) which is a measure of banks' profitability. The positive and significant relationship between capital adequacy and banks' profitability suggest that banks with more equity capital are perceived to have more safety and such advantage can be translated into higher profitability. The higher the capital ratio, the more profitable a bank will be. Based on the findings, it was recommended that there should be a constant review of minimum capital requirement of deposit money banks in Nigeria to the optimal level. Also, Nigeria banks should be well capitalized to enable them enjoy assess to cheaper sources of funds with subsequent improvements in profit levels; this would go a long way to help the public maintain confidence in the banks and also accommodate the credit needs of customers.

Agbeja, O., Adelakun, O.J., \& Olufemi, F. I. (2015), examined whether or not capital adequacy ratio affects bank profitability, it also analyzes the effect of loans and advances on bank profitability as well as the impact of capital adequacy ratio on banks' exposure to credit risk. They were prompt to point out that capital base which was previously two (2) billion naira as at 2004 became grossly inadequate to meet domestic and global realities in the financial system and hence, it was upwardly reviewed to twenty-five (25) billion naira. The study utilized secondary data covering five years financial statement taking case studies of five selected commercial banks. The positive and significant relationship between capital adequacy and bank's profitability suggests that banks with more equity capital are perceived to have more safety and such advantage can be translated into higher profitability. The higher the capital ratio, the more profitable a bank will be. It was recommended that there should be a constant review of minimum capital requirement of deposit money banks in Nigeria to the optimal level and Nigeria banks should be capitalized to enable them enjoy assess to cheaper sources of funds with subsequent improvements in profit levels. This would go a long way in helping the public maintain confidence in the banks with the latter acquiring corresponding enablement to accommodate the credit needs of customers and safeguard depositors' funds.

Jalloh (2017), examined the Impact of Capital Adequacy on the Performance of Nigerian Banks using the Basel Accord Framework. Data was collected using the cross-panel methodology from nine deposit money banks with significant foreign operations. The results of the ordinary least square (OLS) regression show that 76 per cent (R2) of the variations in Profit After Tax (PAT) were caused by independent variables. The study further shows that a unit change in total assets (TA), Loans and Advances (LA), Customer Deposits (CD) and Owners Capital (OC) led to 4.1, 1.6, 3.7 and 1.7 per cent change in PAT respectively. Jalloh noted that Capital adequacy is sufficiency of the amount of equity to absorb any unexpected shocks that a bank may face. According to the Capital Adequacy Standard set by the Bank for International Settlements (BIS), banks must have a primary capital base equal at least to 8 per cent of their assets. Since bank-specific characteristics differ in Nigeria, the Central Bank of Nigeria (CBN) set an arbitrary N25 billion minimum capital base after considering all capital adequacy variables (total assets, owners' funds, customers' deposits and loans and advances) to forestall all future financial downturns. The study therefore recommends that the banks' regulators should not only focus on Capital Adequacy but also on supervisory review and market discipline (1-R2) to maintain banks' financial strength and stability in Nigeria.

Gabriel,Benedict \& Lilian (2018), analyzed the bank-specific determinants of CAR in the Nigerian Deposit Money Banks (DMBs) using balanced panel data collected from financial statements of 12 selected quoted banks 
for the ten-year period 2005-2014. Amongst Capital Adequacy determinants considered (Risk-weighted Asset Ratio, Deposit Asset Ratio, Assets Quality Ratio Returns on Assets), the index for profitability which is ROA was found to be the most important determinant of CAR, having recorded the highest coefficient in the multiple regression result. The study found out that Capital Adequacy Ratio of Nigerian deposit money banks is well above the regulatory minimum set by $\mathrm{CBN}$ as well as the requirements of Basel Accord. Also, Nigerian banks' risk portfolio is quite high and ROA is quite low. Depositors' interests are well protected as the asset base of DMBs is well above the total deposits. The study concludes that CAR is largely determined by banks risk-portfolio, deposit level, profitability and asset quality and that CAR of Nigerian banks is well above the regulatory minimum. The study recommends that Nigerian deposit money banks should adopt a more pragmatic risk-management mechanism and a risk-based capital maintenance approach backed by a robust data management system. The study recommends improvement in operational performance of banks, strict compliance with various capital regulations, frequent stress tests for banks and more detailed disclosure practice to include details of changes in Tier I and Tier II capital, risk-weighted assets and trend analysis of changes in Capital Adequacy Ratio. Amongst the reviewed literatures, there is none that suggests that the increment in banks capital base from the previous two (2) billion naira to twenty-five (25) billion naira has not engendered growth. The BIS standard puts banks capital base at $8 \%$ of its assets-thus, as much as Jalloh (2017) sees the 25 billion naira as arbitrary, the BIS standard did explains what the capital base should be when compared with assets but never state the basic capital base requirement (specific) for banks survival in third world; and developed economy's.

\subsection{Methodology}

\subsection{Introduction}

It describes, to significant users, how hypotheses were tested and the basis for which conclusions were drawn.

This research work borders on the Effects of CAR on Profitability of DMB's in Nigeria.

\subsection{Research Design}

The data used are secondary data s. This method of data collection was determined by factors such as the research topic and purpose.

\subsection{Population of the Study}

The population of this study is based on the RoA and CIT returns of Zenith Bank, Access Bank, UBA, First Bank, Union Bank, Fidelity Bank, First City Monument Bank (FCMB) and Guaranty Trust Bank for the year 2017.

\subsection{Sample Size and Sampling Techniques}

Eight DMB's operates with international operating license in Nigeria and these eight from the international operations strata are all considered.

\subsection{Source and Method of Data Collection}

All data used in the analysis are from secondary source otherwise known as secondary data culled from the annual report of the considered banks.

\subsection{Technique and Instruments of Data Analysis}

Statistical Package for Social Scientists (SPSS) version 17.0 was employed to analyze the data while Multiple Regression analysis was used to test the hypotheses formulated.

\subsection{Model Specification}

Regression analysis models are used to help us predict the value of one variable from one or more other variables whose values can be predetermined. Economic indicators will be utilized in carrying out this data analysis for effective comparison. The Econometric Model is as follows:

Thus: $\mathrm{RoA}_{i}=\beta_{0}+\beta_{1} \mathrm{CAR}_{i}+\mu_{i}$

Where:

Return on Assets (RoA); and

Capital Adequacy Ratio (CAR). 
4.0 Data Presentation, Analysis and Interpretation

4.1 Data Analyses

Table 4.1

Coefficients $^{\mathrm{a}}$

\begin{tabular}{|c|c|c|c|c|c|}
\hline \multirow[t]{2}{*}{ Model } & \multicolumn{2}{|c|}{ Unstandardized Coefficients } & Standardized Coefficients & $\mathbf{t}$ & Sig. \\
\hline & B & Std. Error & Beta & & \\
\hline $\begin{array}{ll}1 & \begin{array}{l}\text { (Constant) } \\
\text { CAR }\end{array} \\
\end{array}$ & $\begin{array}{r}-5.947 \\
38.799\end{array}$ & \begin{tabular}{|l|}
2.113 \\
9.963
\end{tabular} & .846 & $\begin{array}{r}-2.814 \\
3.894\end{array}$ & $\begin{array}{l}.031 \\
.008\end{array}$ \\
\hline
\end{tabular}

a. Dependent Variable: RoA

Table 4.2

Model Summary ${ }^{b}$

\begin{tabular}{|l|c|r|r|r|r|}
\hline Model & R & R Square & Adjusted R Square & Std. Error of the Estimate & Durbin-Watson \\
\hline 1 & $.846^{\mathrm{a}}$ & .717 & .669 & 1.12016 & 1.515 \\
\hline
\end{tabular}

a. Predictors: (Constant), CAR

b. Dependent Variable: RoA

Table 4.3

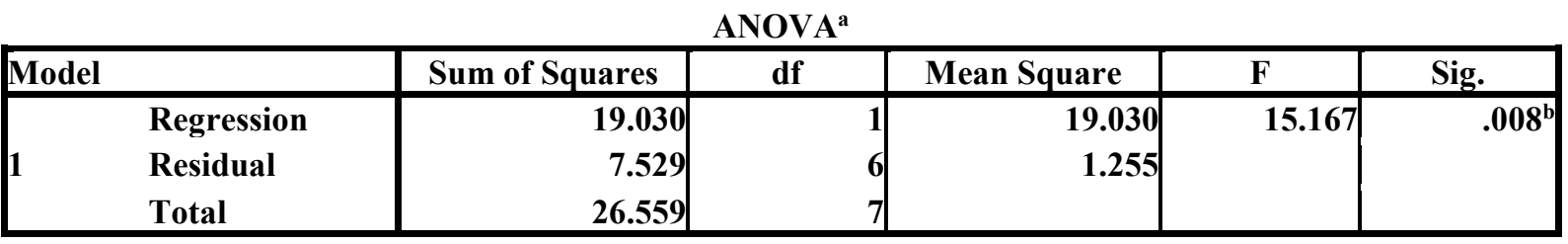

a. Dependent Variable: RoA

b. Predictors: (Constant), CAR

From table $4.1, \mathrm{R}$ is the co-efficient table. Table 4.2 is the model summary table, $\mathrm{R}$ is the correlation coefficient which is 0.846, R Square is the Regression Coefficient at 0.717, Adjusted R Square is the standardized regression coefficient at 0.669 . Durbin Watson is the autocorrelation coefficient at 1.515. The Correlation Coefficient $(R)$ explains the strength of relationship between CAR and Profitability of Nigeria's Deposit Money Bank's. R value of 0.846 represents a strong positive relationship between CAR and Profitability of Deposit Money Banks in Nigeria. The Coefficient of Determination $\left(R^{2}\right)$ gives an idea of how much of the variance in the dependent variable (CIT) is explained by the model. This indicates that our model explains $71.7 \%$ of the variance in Corporate Profitability.

Hence, to test the significance of the parameter estimates, F-statistic was used.Adjusted Coefficient of Determination is used when a small sample is involved $(\mathrm{N}<30)$, the $\mathrm{R}$ square value tends to be a rather optimistic overestimation of the true value of the population (Yomere \& Agbonifoh, 1999), thus, the Adjusted R square statistic corrects this value to provide a better estimate of the true population. In this case, we have 8 observations which is small, thus the normal R squared value is better off at $71.7 \%$ shared variance over the Adjusted R squared at $66.9 \%$ shared variance.

From table 4.3, the F value of 15.167 is the one-way ANOVA result that tests the overall reliability of the parameter estimates.

\subsection{Model Presentation}

From the beta coefficients, the research model for the period can be presented thus:

$\mathrm{RoA}=-5.947+38.799 \mathrm{CAR} i+\mu i------------[$ Research Model $]$

From the research model, the beta coefficient is -5.947 while the 38.799 is the Capital Adequacy Ratio coefficient for the model.

\subsection{Test of Hypothesis}

The null hypothesis $\left(\mathrm{H}_{0}\right)$ will be tested using F-test. F-test was used to evaluate the overall significance of the model. The level of significance $(\alpha)$ used is five per cent $(5 \%)$ at 0.05 .

Decision rule for the F-test is such compares the confidence level and the p-value of the parameter estimates. According to Gujarati \& Potter (2009) as cited in Ajayi, Ajayi, Enimola \& Orugun (2019), if the p-value is less than the confidence level, the null hypothesis is rejected. Therefore;
let:

$\begin{array}{ll}\mathrm{p} \text {-value } & \lambda \\ \text { Confidence Level }= & \alpha\end{array}$

Thus if: $\lambda \leq \alpha$

(Reject $\mathrm{H}_{0}$ ) 
10.7176/RJFA

$\begin{array}{lll} & \lambda \geq \alpha & \left(\text { Accept } H_{0}\right)\end{array}$

Test for null hypothesis $\mathrm{H}_{0}$, by using $\mathrm{F}$-test thereby comparing $\mathrm{p}$-values for the parameter estimate at a confidence level of $5 \%$.

Null Hypothesis

This test on this null hypothesis is to be carried out using F-test. Its stated thus;

$H_{0}$ :There is no strong and positive relationship between Capital Adequacy and Profitability of Deposit Money Banks in Nigeria (DMB's).

$\lambda=0.008, \alpha=0.05$ (Where $\lambda=p$-value and $\alpha=$ confidence level at $5 \%$ )

But: $\lambda \leq \alpha: 0.008 \leq 0.05 \quad$ [Reject $\left.\mathrm{H}_{01}\right]$

Therefore; the null hypothesis that Capital Adequacy Ratio (CAR) does not have a strong and positive relationship with Corporate Profitability of Deposit Money Banks in Nigeria (DMB's is rejected.

\subsection{Discussion of Findings}

Findings shows there exists a strong positive correlation of 0.846 (84.6\%) between Capital Adequacy Ratio (CAR) and Profitability of Deposit Money Bank's in Nigeria.

\subsection{Summary, Conclusion and Recommendations \\ 5.1 Summary}

The study examines the effect of Capital Adequacy Ratio (CAR) on Profitability of DMB's in Nigeria with deliberate focus on the Deposit Money Banks with international operating license in Nigeria for the year 2017.

\subsection{Conclusion}

From the findings, we can conclude that there exists a strong positive relationship between Capital Adequacy and Profitability of DMB'S in Nigeria. Thus; CAR proves a strong factor in profit planning and capital structure decisions.

\subsection{Recommendation}

In consonance with Jalloh (2017), the study therefore recommends that the banks' regulators should not only focus on Capital Adequacy but also on strategic monitoring and evaluation to maintain banks' financial strength and stability in Nigeria. Achieving Capital Adequacy and Sustaining Capital Adequacy are both important for enhanced operational efficiency of DMB's in Nigeria.

\section{References}

Abba, G.O., Inyang, E.E. Zachariah P. (2013). Capital Adequacy Ratio and Banking Risks in the Nigeria Money Deposit Banks. Research Journal of Finance and Accounting. Vol. 4(17).

Agbeja, O., Adelakun, O.J., \& Olufemi, F. I. (2015). Capital Adequacy Ratio and Bank Profitability in Nigeria: A Linear Approach. International Journal of Novel Research in Marketing Management and Economics. Vol. 2(3).

Ajayi, S.O., Ajayi H.F., Enimola, D.J., \& Orugun, F.I. (2019). Effect of Companies Income Tax on Profitability of Deposit Money Banks (DMB's): A Study of Selected DMB's with International Operating License in Nigeria. Developing Country Studies. Vol:9(4).

Aruwa, S.A.S. \& Naburgi, M.M. (2014). Impact of Capital Adequacy on the Financial Performance of Quoted Deposit Money Banks in Nigeria. 4th International Conference of Faculty of Administration, Nasarawa State University, Keffi, Nasarawa State, Nigeria, At Nasarawa State, Nigeria. Volume: 4

Asikhia O. \& Sokefun A. (2013). Capital Adequacy and Banks' Profitability: An Empirical Evidence from Nigeria. American International Journal of Contemporary Research. Vol. 3(10).

Ayodokun,A. (2013). Trend Analysis of the Effect of Capital Base Requirement on Profit Generating Capacity and Operational Efficiency of Selected Commercial Banks in Nigeria. Research Journal of Finance and Accounting. Vol.4(17)

Brian, B. (2018, July 19). What Does a High Capital Adequacy Ratio Indicate? Investopedia. Archived at https:/www.investopedia.com/ask/answers/040115/what-does-it-mean-when-company-has-high-capitaladequacy-ratio.asp [Retrieved 30/4/2019]

Calem, P., \& Rob, R. (1999). The impact of Capital-Based Regulation on Bank Risk-Taking. Journal of Financial Intermediation 8, 317-352.

Cham, Y., Greenbaum, S., \& Anjan, T. (1992). Is Fairly Priced Deposit Insurance Possible” Journal of Finance, 47, pp. 227-245.

Eze, O. (2014). Determinants of Bank Profitability in Nigeria. MPRA Paper. No. 60948. Archived at http://mpra.ub.uni-muenchen.de/60948/ [Retrieved 30/4/2019] 
Flannery, M. (1989). Capital Regulation and Insured Banks "Choice of Individual Loan Default Risks", Journal of Monetary Economics, 24, pp.235-258.

Gabriel, O.A., Ene, O., Benedict, S. \& Lilian N. A. (2018). Determinants of Capital Adequacy Ratio of Deposit Money Banks in Nigeria. Journal of Accounting \& Marketing. Vol 7 (2).

Jalloh, M.A. (2017). Impact of Capital Adequacy on The Performance of Nigerian Banks Using the Basel Accord Framework. East Africa Research Papers in Business, Entrepreneurship and Management. EARP-BEM No. 7

Ndifon, O.E \& Ubana, U.I. (2014). The Impact of Capital Adequacy on Deposit Money Banks' Profitability in Nigeria. Research Journal of Finance and Accounting. Vol. 5(12).

Nyong, O. M. (2001). Monetary Policy and Commercial Banks' in Nigeria: Some Theoretical and Empirical Extensions. CBN Economic and Financial Review, Vol.34, No.3: 777-795.

Richard, A.B. \& Stewart, C.M. (1996). Principles of Corporate Finance. McGraw-Hills Companies

Yomere O. \& Agbonifoh A. (1999). Research Methodology in the Social Sciences and Education. Benin City, Nigeria: Centre Piece Consultant ltd 